\title{
Pola Defekasi pada Anak
}

\author{
Edi S. Tehuteru, Badriul Hegar, Agus Firmansyah
}

\begin{abstract}
Defekasi merupakan salah satu aktivitas manusia yang harus dilalui di dalam kehidupan sehari-harinya. Pola defekasi pada anak sangat bervariasi dan sangat bergantung pada fungsi organ, susunan saraf, pola makan, serta usia anak. Menilai pola defekasi pada anak berarti menilai frekuensi defekasi, konsistensi dan warna tinjanya. Berdasarkan penelitian yang telah dilakukan di beberapa negara di Amerika, Eropa, dan Asia-Pasifik diketahui bahwa terjadi penurunan frekuensi defekasi sesuai dengan bertambahnya usia anak, sedangkan perubahan konsistensi dan warna tinja sesuai dengan pola makan. Sejauh ini belum pernah dilaporkan tentang pola defekasi pada anak Indonesia.
\end{abstract}

Kata kunci: pola defekasi, konstipasi, diare.

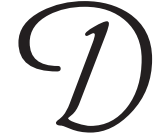

efekasi merupakan salah satu aktivitas manusia yang tidak mungkin terlewatkan di dalam kehidupannya, baik pada anak maupun orang dewasa. Secara definisi, defekasi merupakan suatu proses evakuasi tinja dari dalam rektum, yaitu bahan yang tidak digunakan lagi dan harus dikeluarkan dari dalam tubuh.

Orang tua tidak jarang membawa anaknya ke dokter dengan keluhan buang air besar yang terlalu sering atau tidak buang air besar dalam beberapa hari, yang ternyata pada pemeriksaan selanjutnya terbukti tidak ada kelainan. Berdasarkan keadaan tersebut, timbul suatu pertanyaan "Bagaimana sebenarnya pola defekasi pada anak?” Diperlukan kehati-hatian dalam menentukan apakah seorang anak mengalami gangguan defekasi. Frekuensi defekasi yang berkurang atau berlebihan tidak cukup mencerminkan adanya gangguan defekasi, karena harus pula diperhatikan konsistensi dan warna tinjanya.

Penelitian mengenai pola defekasi pada anak

Subbagian Gastroenterologi. Bagian Ilmu Kesehatan Anak, Fakultas Kedokteran Universitas Indonesia, Jakarta (Dr. Badriul Hegar, Sp.A. Prof. DR. Dr. Agus Firmansyah, Sp.A(K).S)

Alamat korespondensi:

Dr. Edi S Tehuteru.

PPDS Bagian Ilmu Kesehatan Anak, Fakultas Kedokteran Universitas Indonesia, Jl. Salemba No. 6. Jakarta 10430.

Telepon 021-314 8610. Fax. 021-390 7743. sebenarnya sudah dilakukan sejak tahun $1952 .{ }^{1}$ Pada umumnya, penelitian tersebut mengkaji pola defekasi berdasarkan kelompok umur dengan memperhatikan berbagai faktor yang mungkin dapat mempengaruhinya. Sebagian besar penelitian tersebut dilakukan pada anak di Amerika dan beberapa negara di Eropa, sedangkan di Asia-Pasifik baru Australia dan Thailand yang melaporkan secara lengkap. Pola defekasi pada anak Indonesia sejauh ini belum pernah dilaporkan sehingga diperlukan pengkajian lebih lanjut.

\section{Fisiologi Defekasi}

Proses defekasi melibatkan berbagai organ seperti kolon desenden, sigmoid, rektum, sfingter ani internus dan eksternus, serta beberapa serabut saraf. Proses defekasi berawal dari adanya mass movement dari kolon desenden yang mendorong feses ke dalam rektum. Mass movement timbul lebih kurang 15 menit setelah makan dan hanya terjadi beberapa kali sehari. ${ }^{2}$ Adanya tinja di dalam rektum menyebabkan peregangan rektum dan pendorongan tinja ke arah sfingter ani. ${ }^{2-6}$ Keadaan ini menimbulkan rasa ingin berdefekasi yang selanjutnya terjadi defekasi. Proses defekasi dapat dicegah oleh kontraksi tonik dari sfingter ani internus dan eksternus. Sfingter ani internus merupakan kumpulan otot polos sirkular 
yang terletak pada anus bagian proksimal, sedangkan sfingter ani eksternus terdiri dari otot lurik yang terletak pada bagian distal. Kerja kedua otot tersebut diatur oleh sistem saraf somatik. ${ }^{2-6}$

Regangan pada rektum akan menimbulkan rangsangan pada serabut saraf sensoris rektum. Impuls tersebut akan dihantarkan ke segmen sakrum medula spinalis dan selanjutnya secara refleks melalui serabut saraf parasimpatis nervus erigentes akan dihantarkan ke kolon desenden, sigmoid, rektum dan anus. Isyarat serabut saraf parasimpatis ini berlangsung secara sinergis sehingga menyebabkan gerakan peristaltik usus yang kuat, mulai dari fleksura lienalis sampai ke anus, dan bermanfaat dalam pengosongan usus besar. Selain itu, impuls aferen pada medula spinalis juga menyebabkan refleks lain, seperti bernafas dalam, penutupan glotis, dan kontraksi otot abdomen (otot kuadratus, rektus abdominis, oblik eksternus dan internus). Refleks tersebut juga dapat mendorong feses yang berada di dalam usus ke arah distal. ${ }^{2,4,7}$ Pada saat yang bersamaan dasar pelvis akan terdorong ke arah distal sehingga mempermudah pengeluaran feses.

Pada anak besar, kontraksi sfingter ani eksternus dapat diatur sehingga proses defekasi dapat ditunda sampai keadaan yang memungkinkan. Proses tersebut akan menghilang setelah beberapa menit dan baru akan timbul kembali setelah ada masa feses tambahan yang masuk ke dalam rektum. ${ }^{2,4}$ Bila keadaan ini berlangsung berulang kali atau akibat sensasi yang menurun dapat menyebabkan rasa nyeri pada saat defekasi berlangsung yang pada akhirnya dapat menyebabkan gangguan defekasi seperti konstipasi. ${ }^{4,8}$

\section{Pola Defekasi}

Pola defekasi seorang anak dipengaruhi oleh faktor organik (fungsi organ dan sistem serabut syaraf) dan pola makanan serta usianya. Pada fungsi organ dan sistem saraf yang normal, maka pola makan sangat berperan. Kelompok masyarakat yang mempunyai kebiasaan makan makanan mengandung banyak serat umumnya memperlihatkan frekuensi defekasi yang lebih sering dengan konsistensi yang lebih lunak dibandingkan kelompok masyarakat dengan pola makan yang kurang mengandung serat.

Frekuensi defekasi pada bayi baru lahir lebih sering dibandingkan bayi atau anak yang lebih tua usianya. Hal ini disebabkan oleh beberapa organ dan enzim yang berperan dalam proses pencernaan zat makanan (karbohidrat, lemak, dan protein) belum berfungsi secara optimal. Kejadian di atas bukan merupakan suatu keadaan patologi, namun bila tidak dijelaskan kepada orang tua sering menimbulkan kegelisahan. Aktivitas enzim ini akan bertambah sesuai dengan bertambahnya usia. Aktivitas amilase yang optimal akan tercapai pada usia 12 bulan, lipase mencapai kadar seperti orang dewasa pada usia 24 bulan, sedangkan aktivitas tripsin pada bayi baru lahir sudah sama dengan orang dewasa. ${ }^{9-11}$ Aktivitas laktase meningkat pada trimester ketiga kehamilan dan mencapai puncaknya beberapa minggu setelah lahir. ${ }^{12}$ Bayi normal lebih mudah mencerna dan menyerap lemak yang berasal dari ASI dibandingkan lemak susu sapi atau susu formula, disebabkan ASI mengandung lipase. Selain lipase, ASI juga mengandung amilase dan protease; ${ }^{13,14}$ oleh karena itu sangat penting dan bermanfaat untuk tetap memberikan ASI pada bayi. Bayi baru lahir umumnya mempunyai aktivitas laktase yang belum optimal sehingga kemampuan menghidrolisis laktosa yang terkandung di dalam ASI maupun susu formula juga terbatas. Keadaan ini menyebabkan peningkatan tekanan osmolaritas di dalam lumen usus halus yang mengakibatkan peningkatan frekuensi defekasinya.

Defekasi pada bayi baru lahir diawali dengan keluarnya mekonium. Mekonium adalah tinja yang berwarna hitam, kental dan lengket, seperti karet yang merupakan campuran sekresi kelenjar intestinal dan cairan amnion. ${ }^{15,16}$ Pada keadaan normal, mekonium akan keluar pada 36 jam pertama setelah lahir sebanyak 2-3 kali setiap harinya. ${ }^{15,17,18}$ Pada bayi yang mendapat ASI, kolostrum berperan sebagai laksatif alami yang membantu mendorong mekonium keluar dari tubuh. Kolostrum mulai diproduksi pada akhir kehamilan dan tetap bertahan hingga empat hari setelah kelahiran. ${ }^{19,20}$ Selanjutnya kolostrum akan diganti oleh ASI peralihan yang berlangsung selama 7-14 hari, ${ }^{13}$ pada saat ini warna tinja berubah menjadi coklat dan tidak lagi lengket sehingga bila mengenai kulit mudah dibersihkan. ${ }^{15,19}$ Sedangkan frekuensi defekasi bervariasi antara 1-7 kali perhari. ${ }^{15}$

Setelah ASI peralihan berubah menjadi ASI (yang sebenarnya) warna feses cenderung berubah lagi menjadi berwarna kuning dengan konsistensi lembek. ${ }^{15,19}$ Pada bayi yang mendapat pengganti ASI (PASI), feses yang terbentuk biasanya lebih kental dan warnanya lebih kehijauan. ${ }^{21}$ Bayi yang mendapat PASI, frekuensi defekasinya lebih sedikit dibandingkan bayi yang 
mendapat ASI. ${ }^{22}$ Hormon motilin, yang merupakan suatu suatu hormon polipeptida yang disekresi oleh sel enterokromatin usus, terbukti juga dapat membantu meningkatkan motilitas usus sehingga meningkatkan pula frekuensi defekasi. ${ }^{21,22}$

Pada tahun 1952, Nyhan meneliti 800 bayi baru lahir di Amerika Serikat, mendapatkan frekuensi defekasi rata-rata bayi berusia 1 hari adalah 1,5 kali. Frekuensi ini terus meningkat dengan bertambahnya umur bayi dan mencapai puncaknya pada usia 5 hari, yaitu 4,4 kali setiap harinya. ${ }^{1}$ Peneliti lain juga memperlihatkan hasil yang hampir sama, yaitu 4 kali per hari pada bayi berumur 7 hari. ${ }^{17}$ Penelitian lain yang dilakukan pada kelompok umur yang lebih besar didapatkan frekuensi defekasi yang lebih jarang. Frekuensi defekasi pada anak berusia 8-28 hari, 1-2 bulan, dan 13-24 bulan berturut-turut sebanyak 2,2; 1,8 ; dan 1,7 kali per hari. ${ }^{17}$

Hasil yang sama diperoleh pula oleh peneliti lain. Wolman di Amerika Serikat pada tahun 1957, mendapatkan penurunan frekuensi defekasi pada 1000 anak berusia 12-24 bulan dibandingkan pada masa bayi. Frekuensi defekasi berkurang dari 4 kali per hari pada minggu pertama menjadi 1,7 kali per hari pada usia 2 tahun. Lemoh dan Brooke (Perancis, 1979) juga mendapatkan hasil yang sama pada 55 bayi yang ditelitinya. Weaver dan Steiner (Inggris, 1984) yang meneliti 350 anak berusia 1-4 tahun mendapatkan $85 \%$ anak melakukan defekasi 1-2 kali setiap harinya. ${ }^{23}$ Demikian pula Tham (Australia, 1996) melaporkan bahwa $95 \%$ bayi berusia $0-14$ hari mempunyai pola defekasi lebih dari 2 kali per hari, sedangkan pada umur 13-24 bulan hanya ditemukan pada $21 \%$ anak. ${ }^{24}$ Penelitian-penelitian tersebut dilakukan di negaranegara Barat yang tentunya mempunyai pola makan yang berbeda dibanding dengan negara-negara Timur seperti Indonesia, Thailand, Malaysia, dan lain-lain. Salah satu negara di Asia yang pernah melaporkan pola defekasi pada anak adalah Thailand. Osatakul dkk.(1995) meneliti 400 anak sehat berusia 1-72 bulan di Thailand mendapatkan 94\% anak melakukan defekasi lebih kurang 1 kali per hari. Frekuensi defekasi tertinggi terlihat pada periode neonatus yaitu 3,3 kali per hari dan menurun menjadi sekali sehari pada usia 4-6 tahun. Perubahan konsistensi feses dari lunak menjadi berbentuk, sebagian besar mulai terlihat pada anak berusia 4 bulan. Dengan meningkatnya usia, anak-anak menghasilkan feses yang lebih besar pula ukurannya. Mereka juga menyimpulkan bahwa anak- anak di Thailand menghasilkan feses yang lebih besar, lebih lunak, dan frekuensi yang lebih sering dibandingkan anak-anak yang tinggal di negara Barat. ${ }^{25} \mathrm{Hal}$ ini mungkin disebabkan oleh pola makan yang berbeda dan menu makanan Thailand lebih banyak mengandung serat.

Pada penelitian yang dilakukan di Amerika Serikat diketahui bahwa lebih kurang 50\% anak mengkonsumsi makanan berserat kurang dari jumlah serat yang seharusnya dimakan berdasarkan Recommended Dietary Allowances tahun 1989. ${ }^{26}$ Penelitian multisenter di Swedia juga memperlihatkan hasil yang sama, yaitu konsumsi makanan yang berserat sangat rendah sekali. ${ }^{27}$ Untuk menentukan jumlah serat yang harus dikonsumsi oleh seorang anak setiap harinya dapat digunakan suatu rumus yang mudah diterapkan, yaitu umur anak (dalam tahun) ditambah lima. Sebagai contoh, seorang anak yang berusia 4 tahun diharuskan memakan serat sebanyak 9 gram sehari. ${ }^{28}$

Penurunan frekuensi defekasi juga dihubungkan dengan peningkatan waktu singgah makanan di dalam saluran cerna. Waktu singgah di saluran cerna meningkat secara bermakna sesuai dengan bertambahnya usia (Tabel 1). ${ }^{23}$ Sejak mulai diberikan makanan lembek pada usia 6 bulan, saat mulai diperkenalkan berbagai macam makanan termasuk di dalamnya sayur-sayuran, konsistensi tinja tidak lagi lembek atau encer, melainkan sudah mulai berbentuk dan baunya lebih menyengat. ${ }^{18}$ Bentuk tinja pada usia tersebut dikenal dengan istilah banana shaped. Bijibijian seperti jagung dan kacang, mungkin terdapat di dalam tinja bila makanan tersebut diberikan. ${ }^{15}$ Terlihat disini bahwa makanan berserat merupakan rangka dari feses.

Tabel 1. Hubungan antara Waktu Singgah dan Pertambahan Usia ${ }^{23}$

\begin{tabular}{lll}
\hline Peneliti & $\begin{array}{l}\text { Waktu singgah } \\
\text { usia (jam) }\end{array}$ & Usia \\
\hline Lesne (1920) & 8.5 & 1-3 bulan \\
& 10 & $1-2$ tahun \\
Tri Boulet (1909) & 16 & 4-24 bulan \\
Dimson (1970) & 26 & 3-13 tahun \\
Burkitt (1972) & 57 & murid sekolah \\
& $30-48$ & dewasa \\
& $1-2$ minggu & pasien geriatrik \\
\hline
\end{tabular}


Pada usia prasekolah ke atas, anak sudah dapat memilih makanan yang hendak dimakannya. Pola defekasi antara anak yang satu dengan yang lain mulai berbeda tergantung pola makanannya. Anak yang banyak makan makanan berserat akan memperlihatkan defekasi yang lancar, tidak keras, dan teratur. $\mathrm{Hal}$ ini berbeda dengan anak yang tidak suka makan makanan berserat. Mereka umumnya mempunyai pola defekasi dengan tinja yang keras. sehingga tidak jarang menimbulkan rasa sakit pada saat defekasi yang akhirnya dapat menyebabkan konstipasi.

\section{Kelainan Pola Defekasi}

Pola defekasi normal seorang anak perlu dipahami dengan baik karena perubahan pola defekasi dapat merupakan pertanda adanya suatu kelainan yang harus diwaspadai. Dua keadaan yang sering dihubungkan dengan perubahan frekuensi defekasi dan konsistensi tinja adalah konstipasi dan diare. Definisi yang tepat mengenai konstipasi, khususnya pada anak sangat bervariasi. Kesepakatan yang dipakai saat ini untuk mendiagnosis konstipasi adalah (1) frekuensi defekasi kurang dari 3 kali seminggu, atau (2) defekasi dengan tinja yang keras seperti pelet, atau (3) teraba massa tinja pada perut kiri bawah, atau (4) teraba tinja yang keras pada pemeriksaan colok dubur. ${ }^{7,21,29}$ Konstipasi merupakan 3\% kasus dari seluruh kunjungan anak di rumah sakit. ${ }^{29}$ Keadaan tersebut dapat terjadi akibat adanya rasa nyeri pada saat defekasi, sensasi yang menurun, obstruksi mekanis, pseudokonstipasi, atau faktor fungsional. ${ }^{8}$

Walaupun telah dibuat batasan untuk mendiagnosis konstipasi, kita tetap harus memperhatikan adanya perubahan fisiologis pada perkembangan seorang anak. Sebagai contoh, bayi yang mendapat PASI atau baru saja mendapat makanan lumat setelah 4 bulan hanya mendapat ASI dapat memperlihatkan pola defekasi dengan frekuensi kurang dari 3 kali seminggu. ${ }^{18}$ Kejadian ini merupakan suatu hal yang fisiologis, asal gejala klinis konstipasi lainnya tidak ditemukan.

Istilah diare pada anak digunakan bila ditemukan perubahan pola defekasi yang ditandai dengan peningkatan frekuensi defekasi (lebih dari 3 kali sehari) dan konsistensi tinja yang cair. Di Indonesia, diare masih merupakan masalah utama. Hal ini tidak mengherankan mengingat episode diare masih berkisar 60 juta per tahun dengan kematian sebanyak 200.000-250.000 anak. ${ }^{30}$ Diare merupakan suatu gejala klinis yang dapat merupakan petanda adanya penyakit yang sedang diderita oleh seorang anak, seperti infeksi baik di dalam saluran cerna maupun di luar saluran cerna, malabsorpsi, keracunan makanan, alergi makanan, dan lain sebagainya. Pada bayi yang masih mendapat ASI, tidak jarang frekuensi defekasinya mencapai 5-8 kali per hari. Seperti telah diterangkan sebelumnya bahwa keadaan ini adalah fisiologis sehingga tidak memerlukan penanganan khusus. Sebaliknya, kita perlu lebih berhatihati pada seorang anak dengan pola defekasi kurang dari 3 kali sehari tetapi dengan konsistensi tinja yang cair, karena keadaan seperti ini dapat disebut diare. . $^{18,30}$

Warna tinja normal pada anak secara umum adalah kuning/coklat yang disebabkan oleh derivat bilirubin yaitu urobilin dan sterkobilin. ${ }^{2}$ Pada anak yang mendapat PASI tidak jarang tinjanya berwarna kehijauan. Apabila seorang anak memperlihatkan warna tinjanya di luar seperti yang disebutkan di atas, perlu dipikirkan kemungkinan adanya suatu kelainan. ${ }^{21}$ Tinja dapat berwarna seperti dempul karena tidak adanya derivat bilirubin. Apabila keadaan ini terjadi, dapat dipikirkan kemungkinan adanya gangguan pada sistem hepatobilier. Tinja yang berwarna kemerahan atau kehitaman dapat diasumsikan adanya perdarahan saluran cerna. Warna tinja kehijauan ternyata tidak saja terjadi pada anak yang mendapat PASI tetapi dapat pula terjadi pada anak yang menderita diare koleroik. Selain itu ada juga tinja yang menyerupai air cucian beras yang merupakan gejala khas untuk penyakit kolera. ${ }^{6}$

\section{Kesimpulan}

Berbicara tentang pola defekasi pada seorang anak tidak lepas dari pembahasan tentang frekuensi defekasi, konsistensi dan warna tinjanya. Diperlukan pemahaman mendalam tentang pola defekasi pada anak untuk menghindari kesalahan dalam mendiagnosis suatu keadaan yang berhubungan dengan perubahan pola defekasi. Oleh karena pola defekasi pada suatu populasi masyarakat berbeda dengan populasi lainnya, maka perlu dipikirkan untuk mendapatkan data tentang pola defekasi pada anak Indonesia.

\section{Daftar Pustaka}

1. Nyhan WL. Stool frequency of normal infants in the first week of life. Pediatrics 1952; 10:414-25. 
2. Guyton AC. Human physiology and mechanisms of diseases. Edisi ke-3. Philadelphia: Saunders, 1991. h. 57384.

3. Ulshen M. The digestive system. Dalam: Nelson WE, Behrman RE, Kliegman RM, Arvin AM, penyunting. Textbook of pediatrics. Edisi ke-15. Philadelphia: Saunders, 1996. h.1031-2.

4. Busick N, Brander E, Sandra A. Defecation. Didapatkan dari: URL: http.www.vh.org./ Pronders/Textbook/pelvis/ defecation.html.

5. Ismail R, Nur BM, Harjadi FJ. Fisiologi traktus gastrointestinal. Dalam: Suharyono, Boediarso A, Halimun EM, penyunting. Gastroenterologi anak praktis. Jakarta: Balai Penerbit FKUI, 1988. h.1-16.

6. Steffen R, Loening-Baucke V. Constipation and encopresis. Dalam: Wyllie R, Hyams JS, penyunting. Pediatric gastrointestinal disease. Edisi ke-2. Philadelphia: Saunders, 1999. h.43-50.

7. Hatch TF. Encopresis and constipation in children. Pediatr Clin North Am 1988; 35:257-80.

8. Firmansyah A. Konstipasi pada anak. Sari Pediatri 1994; 2:51-6.

9. Lebenthal E, Lee PC. Development of functional response in human exocrine pankreas. Paediatrics 1980; 66:556-60.

10. Lebenthal E. Prolonged small intestinal mucosal injury as primary cause of intractable diarrhea of infancy in chronic diarrhea in children. Dalam: Lebenthal E, penyunting. Chronic diarrhea in Children. New York: Raven Press, 1984. h. 5-25.

11. Lebenthal E. Impact of digestion and absorption in the weaning period on infant feeding practices. Paediatrics 1985; 75:207-13.

12. Hegar B, Buller HA. Breath hydrogen test in lactose malabsorption. Paediatr Indones 1995; 35: 161-71.

13. Lacorence RA. Breastfeeding, a guide for the medical profession. Missouri: Mosby, 1989. h. 505-6.

14. Hamosh M. Digestion in the newborn. Dalam: Neu J, penyunting. Clinics in perinatologi; Neonatal Gastroenterologi. Philadelphia: Saunder, 1996.

15. Sunoto. Keadaan saluran cerna normal. Dalam: Markum AH, Ismael S, Alatas H, Akib A, Firmansyah A, Sastroasmoro S, penyunting. Buku Ajar Ilmu Kesehatan Anak. Jakarta: Balai Penerbit FKUI, 1991. h. 407-8.

16. Dorland's Illustrated Medical Dictionary. Edisi ke-26. Philadelphia: Saunders, 1981.

17. Firmansyah A. Gejala gangguan saluran cerna. Dalam:
Markum AH, Ismael S, Alatas H, Akib A, Firmansyah A, Sastroasmoro S, penyunting. Buku Ajar Ilmu Kesehatan Anak. Jakarta: Balai Penerbit FKUI, 1991. h. 408-12.

18. Condon S. How many times a day does a breasfed baby normally poop? Didapatkan dari: URL: http.//www. Babycenter.com/ refcap/4417.html.

19. Condon S. What's the normal color of a breastfed baby's bowel movement? Didapatkan dari: URL: http.//www. Babycenter.com/expert/8850.html.

20. Hambidge KM, Krebs NF. Nutrition and feeding. Dalam: Merenstein GB, Kaplan DW, Rosenberg AA, penyunting. Handbook of pediatrics. Edisi ke-18. Connecticut: Appleton \& Lange, 1997. h.50-84.

21. Collins S. Baby constipation. Didapatkan dari: URL: http.www.netdoctor.co.ukl health_advicel facts/ babyconstipation.htm.

22. Wilkof W. My nine month old son is passing very hard stools. Is it something he's eating? Didapatkan dari: URL: http.www. Babycenter.com.

23. Weaver LT, Steiner H. The bowel habit of young children. Arch Dis Child 1984; 59:649-52.

24. Tham EB, Nathan R, Davidson GP, Moore PJ. Bowel habits of Australia children aged 0-2 years. J Paediatr Child Health 1996; 6:504-7. (abstrak)

25. Osatakul S, Yossuk P, Mo Suwan L. Bowel habits of normal Thai children. J Pediatr Gastroenterol Nutr 1995; 3:339-42. (abstrak)

26. McClung HJ, Boyne L, Heitlinger L. Constipation and dietary fiber intake in children. Pediatrics 1995; 96:9991001.

27. Hagman U, Bruce A, Persson L, Samuelson G, Sjolin S. Food habits and nutrient intake in childhood in relation to health and socio-economics conditions: A Swedish multicentre study 1980-81. Acta Paediatr Scand 1986; 328:16-7.

28. Baby center. Won't have a bowel movement on the potty. Didapatkan dari: URL: http.www. Babycenter.com/refcap/ 4417. html.

29. Loening - Baucke V. Constipation in early childhood: patient characteristics, treatment, and longterm follow up. Gut 1993; 34:1400-4.

30. Firmansyah A, Suharyono. Penyakit radang usus: infeksi. Dalam: Markum AH, Ismael S, Alatas H, Akib A, Firmansyah A, Sastroasmoro S, penyunting. Buku Ajar Ilmu Kesehatan Anak. Jakarta: Balai Penerbit FKUI, 1991. h. 448-72. 